\title{
Nicotine Addiction : Objective in Educational Programs for Smoking Prevention in Young People
}

\author{
CORINA EUGENIA BUDIN ${ }^{1,3}$, TEODORA GABRIELA ALEXESCUㄴ, IOANA ROXANA BORDEA ${ }^{1}$, \\ MIRCEA CONSTANTIN GHERGINESCU², MARIA ALUAS ${ }^{1}$, BIANCA LIANA GRIGORESCU², LEVENTE BIRO ${ }^{3}$, \\ ANCA DANA BUZOIANU ${ }^{1}$, ROXANA MARIA NEMES ${ }^{4}$, MONICA MARILENA TANTU ${ }^{5}$, DOINA ADINA TODEA ${ }^{1}$ \\ Iuliu Hatieganu University of Medicine and Pharmacy, 4 Louis Pasteur Str., 400349, Cluj Napoca, Romania \\ 2University of Medicine, Pharmacy, Science and Tehnology Targu-Mures, 38 Gh. Marinescu Str., 540139, Targu Mures, Romania \\ ${ }^{3}$ Mures County Hospital, 6 Bernady Gyorgy, 540072, Targu Mures, Romania \\ ${ }^{4}$ Titu Maiorescu University of Medicine, 22 Dambovnicului Tineretului Str. 040441, Bucharest, Romania \\ ${ }^{5}$ University of Pitesti, Faculty of Sciences, Physical Education and Informatics, Medical Assistance and Physical Therapy \\ Department, 1 Targu din Vale Str., Pitesti, 110040, Romania
}

\begin{abstract}
In those countries where education and smoking prevention campaigns are carried out at school level, there has been a decline in the prevalence of smoking among pupils. Nicotine addiction represents a sum of pharmacological, electrophysiological and molecular genetic mechanisms and behavior patterns. The study was conducted from December 2016, to July 2017 and it consisted in an online survey posted on a website. The participants accessed the survey through an e mail link. The study population consisted of 1144 teachers (from primary school, gymnasium and college). The declared percentage of daily smokers was $14 \%$, below the European average, while $20.5 \%$ were declared ex-smokers, $11.2 \%$ were occasional smokers and $54.4 \%$ never smoked. The theme of smoking was approached by $79.2 \%$ of teachers during conducting classes and $81.6 \%$ of them advised smokers to stop smoking. Teachers can influence the pupils' behavior by personal example and byteaching, inside and outside the school, thus preventing nicotine addiction. Decreasing the prevalence of smoking among teachers will inevitably lead in the future to a decrease of adolescentsmokers' incidence. Ourstudy was a pilot project that can draw important directions in educational and preventive campaigns in schools.
\end{abstract}

Keywords: nicotine addiction, smoking, teachers, prevention, school

Smoking is a chronic disease, most of the time originate in adolescence and it causes more than 6 million deaths annually worldwide $[1,2]$. Mortality caused by smoking implies various pathological conditions [3-9], especially neoplasia (bronchopulmonary cancer in particular) $[10,11]$, cardiovascular diseases, obstructive lung diseases and psychiatric diseases.

The smoker's addiction is triggered by nicotine, the main component of cigarette smoke. Nicotine acts on the mesolimbic system in the ventral tegmental area and stimulates dopamine release by exciting glutamatergic terminations [12,13]. Nicotine stimulates neuronal systems and has effects on the cerebral circulation. Children born to smoker mothers have an increased risk of developing hyperactive disorders, thus demonstrating the link between the exposure to tobacco, implicitly to nicotine, and the brain circuits that control attention [12].

Nicotine addiction represents a sum of pharmacological, electrophysiological and molecular genetic mechanisms and behavior patterns [12]. Heavy smokers were shown to have an up regulation of the nicotinic acetylcholine receptors (nAChRs). The binding of nicotine to these receptors, which are normally ligand-gated cation channels for endogenous acetylcholine, triggers the release of neurotransmitters such as dopamine, serotonin, gamma aminobutyric acid (GABA). The main function of the physiological effects produced by nicotine is achieved by the alph 4 and beta 2 subunits of the nicotinic acetylchline receptors. The most common genetic alteration demonstrated in smokers, in both Asian and European populations, is at the level of chromosome 15q25.1 [13].
These genetic modifications, both at the level of chromosome 15q25.1 and 8p11.21, explains the different responses in individuals to tobacco addiction, including the age of onset, induced pathology and severity of evolution $[13,14]$.

The studies on the metabolization and effects of nicotine are at the basis of the development of therapies used for giving up smoking [15]. One of the weak points of such programmes using medications for mental-behavior support was the risk of onset or aggravation of major depressions, especially in adolescents and young adults. In reality there is a bidirectional relationship between depression and smoking. Daily smoking during adolescence increases significantly the risk of developing major depressions at the adult age [12].

There is a balance between the genetic inheritance and the environment. Though it seems that the modification of gene rs 16969968 at the chromosome 15 increases the risk of developing tobacco addiction, the interaction with the environment by educational measures has an equal importance in the personal development of the child and adolescent. Thus, the presence of genetic alterations does not imply that smoking and tobacco addiction at an adult age are inevitable [14-16].

World Health Organization shows a prevalence of current tobacco use in youth for Romania as $11.2 \%$ for both genders ( $12.2 \%$ males, $10.1 \%$ female). [17] World Health Organization included youth ages over 15 and adults in Global Adult Tobacco Survey (GATS), and the results for daily adult smoking in Romania were $24.3 \%$ for both genders (34.9\% for male,14.5\% for female)[16]. The earlier 
the subjects start using alcohol or tobacco, the higher their vulnerability will be for the development, abuse or dependence of the same substances[19,20]. Therefore, an efficient tobacco prevention could be beneficial to control other addictions [21]. These education measures mean that a healthy lifestyle needs to be instilled, in the family, school and teachers $[13,14,16]$. A teacher education campaign on smoking cessation counseling is necessary to be able to promote the recommendations of the World Health Organization.

Studies have shown that in countries where education and smoking prevention campaigns are carried out at school level, there has been a decline in the prevalence of smoking amongst teenagers [22] In these educational programs, teachers play a key role, both through the personal example and the disseminated information.

Teachers can provide smokers with minimal advice on smoking cessation, and can be the ideal partner for smoking prevention campaigns among target age groups. An informed teacher, like an informed physician, can faithfully disseminate accurate information to those to whom the message is addressed [23]. In this case, the message is one for health, for preventing and combating smoking among children and adolescents.

The aim of our study was to assess the prevalence of smoking among teachers in Romania and also the level of knowledge about preventing and cessation tobacco use.

\section{Experimental part}

Our study was conducted between December 2016 and July 2017. The study consisted of an online survey posted on a website. The participants accessed the survey through a link received by e-mail.

The study population consisted of teachers (from primary school, gymnasium and college) from the data base of the Education Department of Romania.

From the database, 1144 teachers responded by completing correctly the survey $(76.26 \%)$. The participants did not have prior knowledge about the prevalence of tobacco use among teachers in Romania.

The questionnaire used included 20 items about current tobacco use, number of cigarettes consumed daily, knowledge about tobacco use, youth education and about age and school. All questions were single response. The questionnaires have been adapted from those used by the GATS (Global Adult Tobacco Survey) and GSPS (Global Tobacco Surveillance System) 2009 Romania, with the aim of using internationally accepted information. Global Core Questionnaires are exempt from copyright [24].

All participants' responses were automatically recorded and centralized into a database, from which they were subsequently extracted and processed statistically.

\section{Statement of ethics}

The survey was approved by the Romanian Society of Pneumology ethics committee and according to Romanian law, followed current regulations on the protection of personal data [25]. The study also received the approval (No. 443/Nov 2016) of the Ethics Committee of Iuliu Hatieganu University of Medicine and Pharmacy in Cluj Napoca, Romania.

\section{Analysis}

The statistical analysis was based on a group of 1144 respondents who filled in the questionnaire. The descriptive analysis presents the frequency and percentages of the whole group. For data analysis we used the chi square test and the significance threshold was set at 0.05 , a value below being considered statistically significant. The SPSS, Inc. v.25 package was used for processing.

\section{Results and discussions}

Our study group, i.e. questionnaire respondents, included $80.2 \%$ women and $19.8 \%$ men. The majority were in the $31-50$ years age group (34.4\% between $31-40$ years and $35.5 \%$ between $41-50$ years), while $10.8 \%$ were in the $20-30$ years age group, $18.3 \%$ between $51-65$ years and only $1 \%$ over 65 years.

The percentage of self-declared daily smokers was $14 \%$, below the European average, while 20.5\% were former smokers, $11.2 \%$ occasional smokers, and $54.4 \%$ never smoked (table 1).

Among smokers, $84.4 \%$ had $0-5$ cigarettes/day, confirming a low degree of tobacco dependence.

The distribution of teachers according to school cycles was relatively even: $33.8 \%$ primary school, $37.3 \%$ secondary school, $28.8 \%$ high school. The correlation between gender and the smoker/non-smoker status was not significant statistically ( $p=0.79)$ (fig. 1)

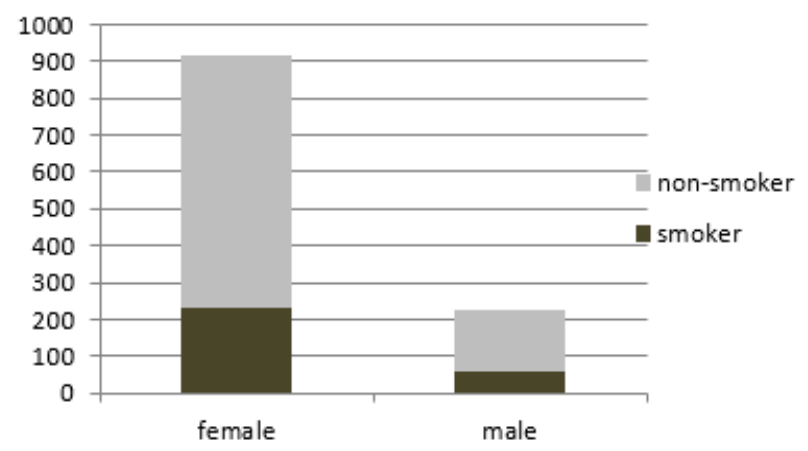

Fig. 1Association between gender and smoker status in the responding teachers. $p=0.79$

Regarding passive smoking, the results were encouraging, as $94.8 \%$ declared not being exposed at home, and $87.4 \%$ were not exposed at work either to the noxious effects of cigarette smoke.

According to the GSPS2009 Romania All Schools, 24\% of the smoker teachers smoked on the school premises; our study evidenced a decrease of passive smoking, given that only $12.6 \%$ declared to be exposed at home or at work. A smoker have a high risk of infections, risk to be admitted in a hospital $[26,27]$.

Only $4.9 \%$ of the respondents were aware that smoking was a disease and not a vice (67.7\%) or a bad habit (23.8\%).

The majority of respondents ( $80 \%$ ) knew the health risks related to smoking, lung cancer being the best known (60.5\%) (table 1).

The association between the smoker status and the importance of prevention emphasized in master classes was statistically significant - $p=0.02(0.05-0.99) R R=0.92$, demonstrating that non-smokers were more keen on this aspect than smokers (fig. 2).

Though most respondents (60.8\%) declared that they knew about tobacco cessation methods in adults as well as teen agers, the answer given was not correct: only $10.4 \%$ chose the correct answer $A$ combination of medicines and psychological support, while $87.7 \%$ answered Personal willpower, which points to the necessity of initiation and continuation of campaigns against smoking for both teachers and students (table 1 ).

In 2009 the World Health Organization provided data on smoking among teachers through the GSPS 2009 Romania All Schools survey. According to this study, $33.5 \%$ of the Romanian teachers were smokers. In our study we found a smaller percentage. The more strictly the national and 
Table I

QUESTIONNAIRE RESPONSES

\begin{tabular}{|c|c|c|}
\hline & & $\mathrm{N}=1144(100 \%)$ \\
\hline \multirow[t]{4}{*}{ Current tobacco status } & Former smoker & $234(20.5 \%)$ \\
\hline & Less than daily & $128(11.2 \%)$ \\
\hline & Daily & $160(14.0 \%)$ \\
\hline & Never smoker & $622(54.4 \%)$ \\
\hline \multirow[t]{2}{*}{ Have you ever used e-cigarette? } & Yes & $60(5,2 \%)$ \\
\hline & No & $1084(94,8 \%)$ \\
\hline \multirow[t]{4}{*}{ What is the definition of smoking in your opinion? } & A disease & $56(4.9 \%)$ \\
\hline & $\mathrm{A}$ vice & $41(3.6 \%)$ \\
\hline & A bad habit & $272(23.8 \%)$ \\
\hline & A behavioral problem & $775(67.7 \%)$ \\
\hline \multirow{2}{*}{$\begin{array}{l}\text { Have you received in the last } 30 \text { days information about the } \\
\text { harmfulness of smoking in the press, TV, internet or other } \\
\text { media? }\end{array}$} & Yes & $745(65.1 \%)$ \\
\hline & No-- & $399(34.9 \%)$ \\
\hline \multirow{2}{*}{$\begin{array}{l}\text { Have you approached the issue of smoking during education } \\
\text { lessons? }\end{array}$} & Yes & $906(79,2 \%)$ \\
\hline & No & $207(18,1 \%)$ \\
\hline \multirow[t]{2}{*}{ Do you know the methods of smoking cessation? } & Yes & $696(60.8 \%)$ \\
\hline & No & $448(39.2 \%)$ \\
\hline \multirow[t]{4}{*}{ What is the most effective way to quit smoking? } & $\begin{array}{l}\text { Combination of drugs and } \\
\text { psychological support }\end{array}$ & $119(10.4 \%)$ \\
\hline & Only psychological support & $20(1.7 \%)$ \\
\hline & Only medical treatment & $2(0.2 \%)$ \\
\hline & Your own will & $1003(87.7 \%)$ \\
\hline \multirow[t]{5}{*}{ What diseases do you know caused by smoking? } & Cardiovascular diseases & $61(5.3 \%)$ \\
\hline & Respiratory diseases & $107(9.4 \%)$ \\
\hline & Various forms of cancer & $58(5.1 \%)$ \\
\hline & All above & $915(80 \%)$ \\
\hline & There are no risks & $3(0.3 \%)$ \\
\hline
\end{tabular}

Table 1 uses descriptive statistics to present the questionnaire responses by percentages

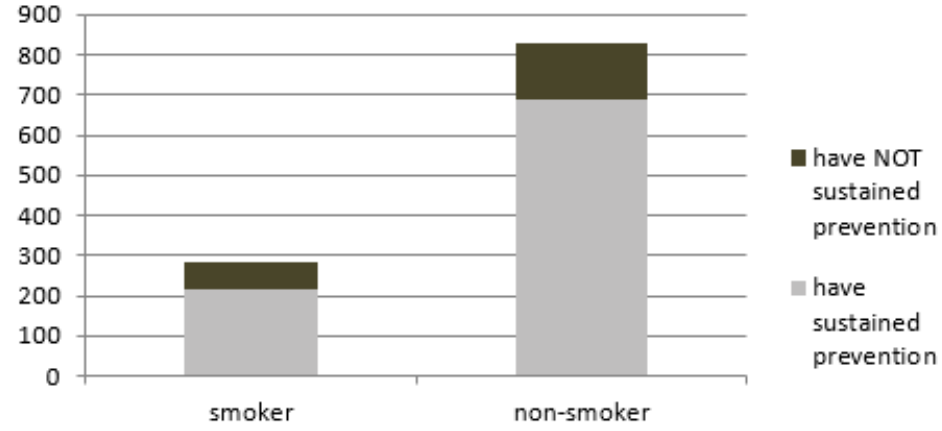

local policies will be applied at the school level on smoke ban, the less probable will it be that teenagers initiate and continue smoking [28]. The younger the age smoking starts, the higher the dependence in adulthood. The greater and longer term the exposure to smoking, the earlier the smoking-related diseases will appear and the more severe $[2,29]$.

The necessity to implement educational programs for teachers may be expanded to all the countries of East Europe. [30] The data obtained from the neighbor countries of Romania (Poland, Hungary) show a decrease of smoking following the application of education programs [31] . The proportion of smoker teachers in our study is comparable with the current European data (27.8\% in Turkey), though much above the level stipulated by WHO [32].

The major objective of this study was the education of teachers in order to enable them to convey a correct and well documented message regarding smoking. Though not supported by the government, a majority of teachers tackled the subject in class, and advised smoker pupils to stop.

Media campaigns (radio, TV, newspapers) should play an important role in smoking prevention, nonetheless only $62.3 \%$ declared receiving such information in the past 30 days. Smoking is a chronic disease according to W HO [33] and have a high risk for cardiovascular diseases [34]. However, the percent of respondents who know the correct definition is low, which indicates that anti-smoking campaigns should be permanent in order to prevent tobacco-related diseases.

After the new law that bans smoking in public places (including schools, hospitals, institutions) in Romania was implemented, the exposure to passive smoking decreased significantly, representing a considerable gain in the fight for prevention against noxious effects of smoking, especially in the young population. Smoking prevention, 
both active and passive, together with indoor and outdoor pollution fight, are all important measures of improving the health condition of the population $[35,36]$.

Systemic inflammation correlated with smoking is present in both active and passive smokers. The presence of systemic inflammation may be documented by increased serum levels of inflammation biomarkers, such as C reactive protein, II-1, II-6, IL-8, interferon- $\gamma$, tnf-ALPHA, fibrinogen [37]. These changes demonstrated in adulthood $[38,39]$ occur in adolescence, from the start of the exposure to cigarette smoking. The longer the exposure, the more chronic the inflammation, which becomes a precarcinogenic mechanism.

There is a demonstrated correlation between the exposure to smoke particles and the sensitization of the airways by inflammation, clinically expressed by bronchial hyperreactivity. The effector cells involved in the inflammation of the bronchial tree are represented by neutrophils, macrophages, dendritic cells and eosinophils [40].

Second and third-hand smoking was recognized as a risk factor of bronchopulmonary cancer in adult nonsmokers. The risk may be documented by determining specific biomarkers such as 4-(methylnitrosamino)-1-(3pyridyl)-1-butanol si 1-(methylnitrosamino)-1-(3-pyridyl) butan-4-ol (iso-NNAL), which result from the metabolization of tobacco specific nitrosamines dosaged from surfaces [41].

In order to prevent these potential health risks, the education programmes should target adolescents, the most vulnerable age group for smoking initiation, and also those who could influence their behavior: family, teachers, doctors [42].

However, not all teachers are totally prepared, as the fight against smoking and educational programs have not represented a public health priority so far [30], as reflected by our study [43-46].

Also, seeing the recent tendencies of using other products containing nicotine, such programs should target a realistic awareness regarding cigarette smoking and use of heated tobacco products or e-cigarettes [31]. Though the cardiovascular effects of cigarette smoking are not evidenced in e-cigarette smokers at the same intensity, cardiac frequency and the risk of heart failure were shown to be increased after vaping. The risk of e-cigarettes is related to the pharmacological effects of nicotine [37] .

The proportion of Romanian teachers who smoke has been decreasing in the last years, but further educational programs are necessary, as the few er teachers will smoke, the smaller will be the number of smoking teenagers in the future.

Teachers can influence the pupils behavior by personal example and by teaching, inside and outside the school, thus preventing nicotine addiction and other future bad behaviors.

Starting with the premise that nicotine addiction is a sum of pharmacological, genetic and environmental factors, our study represents a pilot project that may point to important directions in the prevention campaigns, with long-term benefits for a healthy life style of the young population.

Acknowledgments: The project is part of the main project ANF (Azi Nu Fumez - Today I don't smoke) developed by the Eldad Association of Targu Mures in partnership with the Romanian Society of Pneumology and the University of Medicine and Pharmacy Iuliu Hatieganu Cluj Napoca.

\section{References}

1.*** NATIONAL CENTER FOR CHRONIC DISEASE PREVENTION AND HEALTH PROMOTION (US) OFFICE ON SMOKING AND HEALTH. 2014, PMID: 24455788

2. D'ANGELO, D., AHLUWALIA, IB., PUN, E. et al., MMWR Morbidity and Mortality Weekly Report, 65, 2016, p: 898-901.

3.TANTU, M.M., MAN, G.M., ROGOZEA, L.M. et al., Rom J Morphol Embryol., 59, no. 3, 2018, p: 895-902

4.TANTU, MM., MAN, G.M., PAUNESCU, A. etal., Rev.Chim.(Bucharest), 70, no.4, 2019, p. 1307

5.TEREANU, C., BAILI, P., BERRINO, F., MICHELI, A., FURTUNESCU, FL. et al. Eur J Cancer Prev; 22, no. 3, 2013, p:199-209.

6.NITU, FM., OLTEANU, M., STREBA, CT. et al. Romanian JournaL of Morphology and Embryology, 58, no. 2, 2017, p: 385-392

7.STEFANESCU, D.C., CEACHIR, 0., ZAINEA, V. et al. Rev. Chim.(Bucharest), 67, no.7, 2016, p: 1327-1328

8.STEFANESCU, D.C., CEACHIR, 0., ZAINEA, V. et al. Rev. Chim.(Bucharest), 67, no.7, 2016, p. 1255-1256

9.GRIGORIU, ME., COSTEA, RV., GRIGORIU, Cl., FURTUNESCU, FL., Medical-Surgical J ournal, 122, no.1, 2018, p:102-108

10.AVRAMOIU, I., PETRESCU, IO., CIUREA, ME. et al., Rom J Morphol Embryol, 57, no. 3, 2016, p:943-950

11.DIACONESCU, DE., DIMA, L., MARINESCU, DM., TANTU, MM., ROGOZEA, LM., Rom J Morphol Embryol, 55, no. 4, 2014, p:1371-1375 12.PICCIOTTO, MR., MINEUR, YS., Neuropharmacology, 76, 2014, p: 545-553.

13.LOUKOLA, A., HALLFORS, J., KORHONEN, T. et al., Current Addiction Reports, 1, 2014, p: 75-82.

14.VINK, JM., J Stud Alcohol Drugs, 77, 2016, p: 684-687.

15.POSTOLACHE, P., NEMES, RM., PETRESCU, O. et al. Medical-surgical Journal- Revista Medico-Chirurgicala, 119, no. 1, 2015, p: 77-80

16.WAIN, LV., SHRINE, N., MILLER, S. et al., Lancet Respir Med, 3, 2015, p: 769-781.

17.*** WORLD HEALTH ORGANIZATION, Regional Office for Europe. Global Youth Tobacco Survey (GYTS): Romania report (Ages 13-15), 2013.

18.*** W ORLD HEALTH ORGANIZATION, http://www.who.int/tobacco/ surveillance/survey/gats/gats_romania_factsheet_june_27_2012.pdf (accessed 3 J une 2018).

19.DOMNARIU, CD., ILIES, A., FURTUNESCU, FL., RCIS, 41, 2013, p:77-95.

20.LOCATELLI, D., SANCHEZ, Z., OPALEYE, E. et al., Revista Brasileira de Psiquiatria, 34, 2012, p: 193-200.

21.THOMAS, R., PERERA, R., Cochrane Database Syst Rev., 19, no. 3, 2006; p: CD001293.

22.TRINIDAD, DR., GILPIN, EA., PIERCE, JP., Health Education Research, 20, 2005, p: 466-475.

23.IANOSI, E.S., POSTOLACHE, P., MACOVEI, L.A., SZATHMARY, M., SZASZ, S., NEMES, R.M., JIMBOREAN, G., Rev. Chim.(Bucharest), 69, no. 7, 2018, p: 1766-1769.

24.*** WORLD HEALTH ORGANIZATION \& CENTERS FOR DISEASE CONTROL 2011, http://www.who.int/iris/handle/10665/87331

25.POPESCU, IG., SECHEL, G., LEASU, FG. et al., Rom J Morphol Embryol, 59, no. 3, 2018, p:1001-1005

26.TANTU, M.M., MAN, G.M., PAUNESCU, A. et al., Rev.Chim. (Bucharest), 69, no. 11, 2018, p: 3001-3005

27.DUCEAC, LD., TARCA, E., CIUHODARU, MI., TANTU, MM. et al., Rev. Chim.(Bucharest), 70, no. 1, 2019, p:199-201

28.*** WOLD, B., Health Education Research, 19, 2004, p: 217-226. 29.AHRENS, KR., GARRISON, MM., COURTNEY, ME., Pediatrics, 134, 2014, p: 1067-1074.

30.IANOSI, E.S., DANTES, E., CSIPOR, A., SZATHMARY, M., SOCACI, A., RUSU, E., Rev. Chim.(Bucharest), 69, no. 10, 2018, p: 2725-2727

31.NIEDZIN, M., RZE•NICKI, A., WOJTYSIAK, P. et al., Prz Lek, 73, 2016, p: 754-757.

32.MERMER, G., DADHAN, a ., BILGE, A. etal., Central European J ournal of Public Health, 24, 2016, p: 137-143. 
33.GLOBAL TOBACCO SURVEILLANCE SYSTEM DATA (GTSSData), https://nccd.cdc.gov/GTSS/rdPage.aspx?rdReport=OSH_ GTSS. ExploreByLocation\&rdRequestForwarding $=$ Form (accessed 6 November 2018).

34.PLESA, CF., NICOLAE, C., SIRBU, CA., NEMES, R., PAUNESCU, A., TANTU, MM., Farmacia, 67, 2019, p: 27-33

35.DANTE', E., LILIOS, G., FILDAN, A.P., J ournal of Environmental Protection and Ecology (J EPE), 16, no. 4, 2014, p: 1620-1626

36.TODEA, DA., SUATEAN, I., COMAN, AC., ROSCA LE., Notulae Botanicae Horti Agrobotanici, 41, no. 2, 2013, p: 646-650

37.BUDIN, C.E., MARGINEAN, C., BORDEA, IR., ENACHE, LS., ENACHE, EL., GRIGORESCU, B.L. et al., Rev. Chim.(Bucharest), 69, no.12, 2018, p:3659-63.

38. SHIFFMAN, S., DUNBAR, MS., BENOWITZ, NL., Cancer Epidemiol Biomarkers Prev, 23, 2014, p: 1264-1272.
39.NITESCU, M., FURTUNESCU, FL., OTELEA, M. et al., Rev Romana Med Lab., 20, no. 3, 2012, p:207-214

40.PAPPAS, RS., Metallomics, 3, 2011, p: 1181.

41.THOMAS, JL., GUO, H., CARMELLA, SG. et al., Cancer Epidemiol Biomarkers Prev, 20, 2011, p: 1213-1221.

42.J IMENEZ-RUIZ, CA., RIESCO MIRANDA, JA., RAMOS PINEDO, A. et al., Respiration, 90, 2015, p: 474-480.

43.DEWHIRST, S., PICKETT, K., SPELLER, V. et al., J Public Health, 36, 2014, p: 467-475.

44.AGAKU, IT., OBADAN, EM., ODUKOYA, 00. et al., Eur J Public Health, 25, 2015, p: 210-215.

45.TODEA, D., COSMA, C., DICU, T. et al., Environmental Engineering and Management Journal, 12, no 6, 2013, p: 1281 -1285

46.VREMAROIU-COMAN, A., ALEXESCU, TG., NEGREAN, V. etal., Balneo research journal, 9, 2018, p: 254-259

Manuscript received: 19.01 .2019 